\title{
Kualitas Laba dan Tingkat Manipulasi Laporan Keuangan dimata Investor Pasar Modal Sektor Pertambangan. Pentingkah?
}

\author{
Robith Hudaya \\ Universitas Mataram, Nusa Tenggara Barat
}

\begin{abstract}
This study aims to prove empirically whether the earnings quality and the level of financial statement manipulation have an effect on the company market value. The study used sample of 3 years from 2017 to 2019. Using the multiple linear regression method, it was found that the quality of earnings has a negative effect on the market value of the company and is contrary to previous theory and research. Meanwhile, the level of financial statement manipulation has no effect on the company's market value. These results indicate that the quality of earnings and the degree of manipulation of financial statements are not the main information used by capital market players in determining their investment choices. Capital market players prefer other methods of analysis in determining their investment options.
\end{abstract}

Keywords: earnings quality; financial statement manipulation; market value; capital market; investment

\begin{abstract}
Abstrak
Penelitian ini bertujuan untuk membuktikan secara empiris apakah kualitas laba dan tingkat manipulasi laporan keuangan berpengaruh terhadap nilai pasar perusahaan. Penelitian menggunakan sampel selama 3 tahun dari 2017 sampai 2019. Menggunakan metode regresi linier berganda ditemukan bahwa kualitas laba memiliki pengaruh negatif terhadap nilai pasar perusahaan dan bertolak belakang dengan teori serta penelitian terdahulu. Sedangkan tingkat manipulasi laporan keuangan tidak berpengaruh terhadap nilai pasar perusahaan. Hasil ini mengindikasikan bahwa kualitas laba dan tingkat manipulasi laporan keuangan bukan merupakan informasi utama yang digunakan oleh pelaku pasar modal dalam menentukan pilihan investasinya. Pelaku pasar modal lebih memilih metode analisis lainnya dalam menentukan pilihan investasinya.
\end{abstract}

Kata kunci: kualitas laba, tingkat manipulasi laporan keuangan, nilai pasar perusahaan, pasar modal, investasi.

\section{PENDAHULUAN}

Investor cenderung melihat prospek berinvestasi pada sebuah perusahaan berdasarkan nilai perusahaannya (Lestari et al, 2014; Hamdiah, 2015; Zarviana et al, 2017). Semakin baik nilai perusahaan perusahaan, seharusnya akan semakin banyak investor yang tertarik menanamkan modalnya di perusahaan tersebut. Begitu juga sebaliknya, semakin buruk nilai perusahaan, maka investor enggan berinvestasi pada perusahaan tersebut. Hampir dapat dikatakan bahwa nilai perusahaan merupakan satu-satunya indikator utama dalam penentuan keputusan investasi baik itu oleh trade maupun oleh investor.

Trader maupun investor bisa melihat nilai perusahaan pada rasio-rasio keuangan yang dihasilkan dalam laporan keuangan. Ada lima jenis perhitungan rasio keuangan yang digunakan untuk melakukan penilaian perusahaan yaitu rasio aktivitas, rasio likuiditas, rasio solvabilitas, rasio profitabilitas dan rasio valuasi (Robinsonet al, 2015). Kelima rasio ini dapat dijadikan pedoman dalam menentukan baik-buruknya nilai perusahaan, tentunya dengan membandingkannya dengan rasio industri. Jika kelima jenis rasio keuangan tadi lebih baik dari 
rasio-rasio industri, maka nilai perusahaan bisa dikatakan baik. Selain dinilai menggunakan penilaian dari sisi keuangan, perusahaan juga dinilai menggunakan penilaian pasar.

Penilaian pasar dari sebuah perusahaan berpatokan pada harga pasar dari saham beredar. Penilaian pasar banyak digunakan sebagai pedoman oleh trader maupun investor dalam menentukan pilihan investasinya. Banyak faktor yang mempengaruhi bagus tidak nya penilaian pasar sebuah perusahaan antara lain berbagai faktor eksternal seperti adanya kebijakan pemerintah, gejolak pada harga komoditas dan wabah penyakit yang melanda dunia. Selain faktor eksternal, faktor internal dalam perusahaan sendiri yang muncul ke publik seperti berbagai pengungkapan yang dipublikasikan perusahaan ikut mempengaruhi nilai pasar perusahaan. Hasil dari pengungkapan ke publik yang dilakukan oleh perusahaan, dapat menghasilkan informasi berupa penilaian kualitas laba dan tingkat manipulasi laporan keuangan yang seharusnya ikut mempengaruhi nilai dari perusahaan.

Kualitas laba dihasilkan dari arus kas yang masuk kedalam perusahaan akibat adanya penjualan. Semakin tinggi aliran kas yang masuk, maka semakin bagus kualitas laba perusahaan dan penilaian perusahaan meningkat (Lestari et al, 2014; Hamdiah, 2015; Zarviana et al, 2017). Penjualan kredit menyebabkan tingginya piutang yang berpotensi tidak tertagih. Tingginya angka ketidaktertagihan ini akan membuat kualitas laba perusahaan turundan otomatis akan menurunkan kinerja perusahaan. Penelitian sebelumnya menemukan hasil yang sama dimana Lestari et al, (2014) melakukan penelitian pada 24 perusahaan manufaktur dan menemukan bahwa kualitas laba berpengaruh positif terhadap nilai perusahaan. Hamdiah (2015) melakukan penelitian terhadap perusahaan transportasi di Indonesia dan menemukan bahwa kualitas laba berpengaruh positif terhadap nilai perusahaan. Zarviana et al, (2017) melakukan penelitian terhadap perusahaan yang masuk kedalam indeks Kompas 100 dan menemukan temuan serupa.

Selain kualitas laba, tingkat manipulasi laporan keuangan juga dapat membuat penilaian perusahaan terlihat menjadi baik dengan jalan mempengaruhi angka-angka di laporan keuangan sehingga tampak bagus kinerja perusahaan (Tarjo dan Herawati, 2015; Talab et al, 2017; Iswanaji, 2018; dan Hugo, 2019). Investor yang rasional seharusnya tidak menyukai manipulasi laporan keuangan yang dilakukan dalam perusahaan. Setiap investor menginginkan agar perusahaan dikelola dengan baik tanpa adanya manipulasi. Akan tetapi, menurut teori keagenan, hal ini sulit dicapai karena masing-masing pihak dalam perusahaan bertindak mewakili kepentingannya. Manajer sangat berpotensi untuk memanipulasi laporan keuangan perusahaan dengan tujuan agar nilai perusahaan terlihat baik. Semakin bagus nilai perusahaan, maka kinerja individu seorang manajer akan dianggap bagus oleh pemilik perusahaan dan akan meningkatkan bonus kinerja manajer (Watts dan Zimmerman, 1990).

Novriansa (2019) dalam sebuah artikel yang ditulis di DDTC News mengatakan bahwa sektor pertambangan merupakan sektor yang rawan kecurangan dalam hal transfer pricing, penghindaran pajak, dan banyak menimbulkan kerusakan lingkungan Pernyataan ini dapat menjadi tanda dan menarik untuk dapat dibuktikan secara empiris apakah kualitas laba yang dihasilkan perusahaan pertambangan mempengaruhi penilaian perusahaan oleh investor pasar modal. Akibat pernyataan ini, investor perlu waspada terhadap kualitas laba yang dihasilkan oleh perusahaan pertambangan. Jangan-jangan laba yang dihasilkan banyak terjadi karena adanya penjualan secara kredit yang tinggi atau mungkin ada sebab lainnya. Selain itu, perlu dibuktikan juga secara empiris apakah tingkat manipulasi laporan keuangan perusahaan pertambangan berpengaruh terhadap penilaian pasar oleh investor pasar modal.

Selain kedua hal tersebut, hasil penelitian yang dilakukan di Indonesia berkait kualitas laba dan tingkat manipulasi laporan keuangan selama ini tidak ada yang menggunakan sampel perusahaan pertambangan dan belum adanya penelitian yang mengkaitkan pengaruh manipulasi laporan keungan terhadap nilai pasar dimata investor pasar modal sektor pertambangan. Tujuan utama penelitian ini untuk melihat apakah informasi berkait kualitas laba dan tingkat manipulasi laporan keuangan menjadi sumber informasi yang penting dan bermanfaat bagi investor pasar 
modal sektor pertambangan dalam menentukan pilihan investasinya.Hasil dari penelitian ini diharapkan mampu memberi kontribusi kepada para investor maupun calon investor dalam berinvestasi di saham-saham sektor pertambangan.

\section{METODE PENELITIAN}

Penelitian ini dikategorikan sebagai penelitian asosiatif karena bertujuan untuk mencari pengaruh atau hubungan dan menganalisis antara variabel independent terhadap variabel dependen. Populasi yang digunakan dalam penelitian ini adalah laporan keuangan perusahaan pertambangan yang listing di Bursa Efek Indonesia tahun 2017 sampai tahun 2019. Sampel penelitian disaring menggunakan metode purposive sampling. Sampel yang digunakan dalam penelitian ini adalah seluruh perusahaan yang termasuk kategori saham pertambangan dan telah listing di Bursa Efek Indonesia sejak tahun 2017. Untuk periode pengamatan 3 tahun, diperoleh total 141 sampel pengamatan.

Variabel dependen yang dipergunakan dalam penelitian ini adalah nilai pasar dari perusahaan yang akan diproksikan dengan Tobin's Q. Data harga saham, jumlah saham beredar, nilai buku utang dan aset dapat diperoleh melalui laporan keuangan perusahaan. Tobins'Q dapat dihitung dengan rumus:

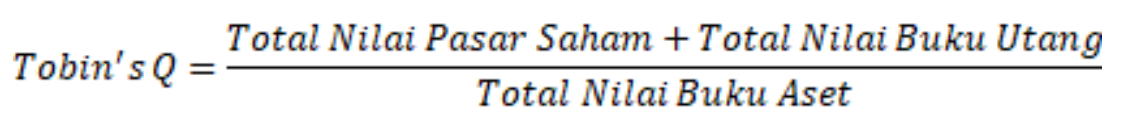

Total Nilai Pasar saham diperoleh dengan mengalikan harga saham dengan jumlah saham beredar perusahaan.

Variabel independent dalam penelitian ini adalah kualitas laba dari perusahaan yang diproksikan dengan discretionary accruals sesuai pengukuran dalam penelitian Yoon et al. (2006). Model pengukuran ini memperbaiki model modified jones yang tidak cocok digunakan untuk perusahaan-perusahaan di Asia (Korean Firms). Selain itu, menurut penelitian Islam et al. (2011), model ini telah terbukti memberikan hasil jauh lebih baik daripada model modified jones pada perusahaan-perusahaan di Banglades (Dhaka Stock Exchange). Berikut model pengukuran discretionary accruals yang digunakan dalam penelitian Yoon et al. (2006):

$$
\begin{gathered}
\mathrm{DA}=\mathrm{TA} / \mathrm{REV}-\left[\beta_{0}+\beta_{1}(\Delta \mathrm{REV}-\Delta \mathrm{REC}) / \mathrm{REV}+\beta_{2}(\Delta \mathrm{EXP}-\Delta \mathrm{PAY}) / \mathrm{REV}+\right. \\
\beta_{3}(\mathrm{DEP}+\mathrm{PEN}) / \mathrm{REV}
\end{gathered}
$$

angka $\beta_{0}, \beta_{1}, \beta_{2}, \beta_{3}$ diperoleh dengan meregresikan persamaan

$$
\mathrm{TA} / \mathrm{REV}=\beta_{0}+\beta_{1}(\Delta \mathrm{REV}-\Delta \mathrm{REC}) / \mathrm{REV}+\beta_{2}(\Delta \mathrm{EXP}-\Delta \mathrm{PAY}) / \mathrm{REV}+\beta_{3}(\mathrm{DEP}+\mathrm{PEN}) / \mathrm{REV}
$$

\section{Dimana}

TA $($ Total Accruals $)=$ Laba Akuntansi-Arus Kas Operasi

REV = Pendapatan Penjualan Bersih

REC $=$ Piutang Usaha

EXP = Jumlah Harga pokok penjualan + beban administrasi dan penjualan dikurangi beban non kas

PAY $=$ Utang usaha

$\mathrm{DEP}=$ Beban Depresiasi

$\mathrm{PEN}=$ Beban Pensiun 
Variabel independent kedua yang digunakan dalam penelitian ini adalah tingkat manipulasi laporan keuangan yang diproksikan dengan Beneish M-Score Model. Ada 8 indikator yang digunakan untuk penilaiannnya yaitu

1. Days Sales in Receivables Index (DSRI)

Pengukurannya sebagai berikut

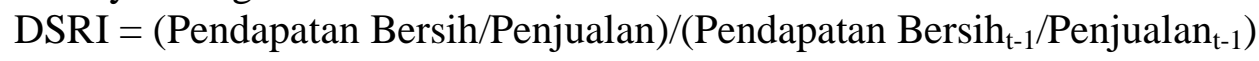

2. Gross Margin Index (GMI)

Pengukurannya sebagai berikut

GMI = (Penjualan-Harga Pokok Penjualan $) /$ Penjualan

3. Asset Quality Index (AQI)

Pengukurannya sebagai berikut

$\mathrm{AQI}=[1-($ Aset Lancar + Aset Berwujud $) /$ Total Aset $] /\left[1-\left(\right.\right.$ Aset Lancar $_{\mathrm{t}-1}+$ Aset

Berwujud $_{t-1}$ )/Total Asset $\left.\left.{ }_{t-1}\right)\right]$

4. Sales Growth Index (SGI)

Pengukurannya sebagai berikut

SGI $=$ Penjualan/Penjualan t -1

5. Depreciation Index (DEPI)

Pengukurannya sebagai berikut

DEPI $=\left(\right.$ Beban Penyusutan $_{t-}{ }_{1} /\left(\right.$ Aset Tetap $_{t-1}+$ Beban Penyusutan $\left.\left._{t-}{ }_{1}\right)\right) /($ Beban Penyusutan/ (Aset Tetap+ Beban Penyusutan))

6. Sales General and Administrative Expenses Index (SGAI)

Pengukurannya sebagai berikut

SGAI $=($ Beban Administrasi dan Penjualan $/$ Penjualan $) /($ Beban Administrasi dan Penjualan $_{\mathrm{t}-1} /$ Penjualan $_{\mathrm{t}-1}$ )

7. Leverage Index (LVGI)

Pengukurannya sebagai berikut

LVGI $=$ Utang/Utang $\mathrm{t}-1$

8. Total Accruals to Total Assets (TATA).

Pengukurannya sebagai berikut

TATA $=($ Laba Akuntansi-Arus Kas Operasi $) /$ Total Aset

Kedelapan pengukuran ini digunakan untuk menghitung Beneish M-Score Model dengan persamaan :

M-score $=-4.84+0.920 * \mathrm{DSRI}+0.528 * \mathrm{GMI}+0.404 * \mathrm{AQI}+0.892 * \mathrm{SGI}+0.115 * \mathrm{DEPI}-$

$0.172 * \mathrm{SGAI}+4.679 *$ TATA $-0.327 *$ LVGI

\section{HASIL DAN PEMBAHASAN}

Statistika Deskriptif

Analisis statistika deskriptif dilakukan untuk mengetahui gambaran umum data yang digunakan dalam penelitia. Analisis dilakukan pada setiap variabel meliputi nilai minimum, maksimum, rata-rata, dan standar deviasi. Berikut adalah hasil analisis statistika deskriptif 
variabel-variabel penelitian yaitu kualitas laporan keuangan, tingkat manipulasi laporan keuangan dan nilai pasar:

Tabel 1. Descriptive Statistics

\begin{tabular}{|c|c|c|c|c|c|}
\hline & $\mathrm{N}$ & Minimum & Maximum & Mean & $\begin{array}{c}\text { Std. } \\
\text { Deviation }\end{array}$ \\
\hline & Statistic & Statistic & Statistic & Statistic & Statistic \\
\hline $\begin{array}{l}\text { Nilai } \\
\text { Perusahaan }\end{array}$ & 90 & 0.247 & 5.350 & 0.89943 & 0.635702 \\
\hline $\begin{array}{l}\text { Kualitas } \\
\text { Laba }\end{array}$ & 90 & -2.097 & 0.957 & 0.00141 & 0.391494 \\
\hline $\begin{array}{l}\text { Manipulasi } \\
\text { LK }\end{array}$ & 90 & -363.660 & 54.459 & $\begin{array}{c}- \\
6.60872 \\
\end{array}$ & 38.673401 \\
\hline $\begin{array}{l}\text { Valid N } \\
\text { (listwise) }\end{array}$ & 90 & & & & \\
\hline
\end{tabular}

Sumber: Data Statistik yang diolah, 2021

Berdasarkan tabel diatas, diketahui bahwa rata-rata dari nilai pasar perusahaan selama 3 tahun adalah 0.899 dimana nilai terendah darii kinerja adalah 0.247 dengan nilai maksimum 5.350. Untuk Kualitas laba, rata-rata perusahaan selama 3 tahun sebesar 0.001 dengan nilai minimum -2.097 dan nilai maksimum 0.957. Terakhir untuk tingkat manipulasi laporan keuangan nilai rata-ratanya -6.609 dengan nilai minimum diketahui -363.660 dan nilai maksimumnya 54.459 .

\section{Pengujian Asumsi Klasik}

Pengujian asumsi normalitas menggunakan metode Kolmogorov-Smirnov di mana residual model dikatakan berdistribusi normal jika nilai signifikansi yang dihasilkan lebih besar dari 0,05. Hasil pengujian normalitas bisa dilihat di tabel berikut:

Tabel 2. Hasil Uji Normalitas

\begin{tabular}{llr}
\hline & & Unstandardized Residual \\
\hline $\mathrm{N}$ & & 90 \\
\hline Normal & Mean & 0.0000000 \\
\cline { 2 - 3 } & Parameters & Std. Deviation \\
\cline { 2 - 3 } Most & Absolute & 0.61203856 \\
\cline { 2 - 3 } Extreme & Positive & 0.155 \\
\cline { 2 - 3 } Differences & Negative & 0.155 \\
\hline Test Statistic & & -0.124 \\
\hline Asymp. Sig. (2-tailed) & 0.155 \\
\hline
\end{tabular}

Sumber: Data SPSS yang diolah, 2021

Berdasarkan hasil pengujiian diatas diketahui bahwa data tidak berdistribusi normal. Oleh karena itu akan dilakukan pembuangan outlier. Hasil uji normalitas setelah outlier dibuang sebagai berikut:

Tabel 3. Hasil Uji Normalitas Setelah Outlier

\begin{tabular}{|c|c|c|}
\hline 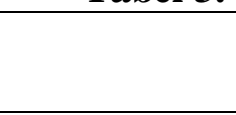 & & $\begin{array}{c}\text { Unstandardized } \\
\text { Residual }\end{array}$ \\
\hline $\mathrm{N}$ & & 89 \\
\hline \multirow{2}{*}{$\begin{array}{l}\text { Normal } \\
\text { Parameters }{ }^{\mathrm{a}, \mathrm{b}}\end{array}$} & Mean & -0.0499599 \\
\hline & Std. Deviation & 0.38943052 \\
\hline
\end{tabular}




\begin{tabular}{llr} 
Most & Absolute & 0.089 \\
\cline { 2 - 3 } Extreme & Positive & 0.089 \\
\cline { 2 - 3 } Differences & Negative & -0.040 \\
\hline Test Statistic & 0.089 \\
\hline Asymp. Sig. (2-tailed) & $.076^{\mathrm{c}}$ \\
\hline
\end{tabular}

Sumber: Data SPSS yang diolah, 2021

Berdasarkan hasil pengujian diatas diketahui bahwa data sudah berdistribusi normal. Selanjutnya akan dilakukan uji asumsii klasik.

\section{Uji Multikolinieritas}

Uji multikolinieritas dilakukan untuk mendeteksi apakah model regresi dalam analisis antar variabel bebas satu dengan variabel bebas yang lain saling berhubungan atau tidak. Model regresi yang terbaik adalah apabila variabel bebas di dalam model regresi tidak saling berhubungan satu dengan yang lainnya. Berikut ini adalah hasil pengujian non multikolinieritas selengkapnya:

Tabel 4. Hasil Uji Multikolinieritas

\begin{tabular}{lllr}
\hline \multirow{2}{*}{ Model } & \multicolumn{2}{c}{ Collinearity Statistics } \\
\cline { 2 - 4 } & & Tolerance & VIF \\
\hline 1 & (Constant) & & \\
\cline { 2 - 3 } & Kualitas Laba & 0.998 & 1.002 \\
\cline { 2 - 3 } & Manipulasi LK & 0.998 & 1.002 \\
\hline \multicolumn{2}{l}{ Sumber: Data SPSS yang diolah, 2021 }
\end{tabular}

Berdasarkan hasil uji non multikolinieritas yang tertera pada tabel diketahui bahwa nilai VIF untuk model regresi telah lebih kecil dari nilai 10, begitu juga untuk nilai tolerance yang semua sudah lebih besar dari 0,1. Dengan demikian, disimpulkan bahwa di dalam model regresi sudah terbebas dari pelanggaran atas asumsi multikolinieritas.

\section{Uji Autokorelasi}

Uji autokorelasi dilakukan untuk mendeteksi apakah model regresi antar nilai residual periode $\mathrm{t}$ memiliki hubungan yang signifikan dengan residual pada periode $\mathrm{t}-1$ dan seterusnya. Model regresi yang terbaik adalah apabila antara residual tidak saling berhubungan dengan periode waktu sesudahnya. Pendeteksian atas asumsi non autokorelasi dilakukan dengan metode run test. Berikut ini adalah hasil pengujian non autokorelasi selengkapnya:

Tabel 5. Hasil Uji Autokorelasi dengan Runs Test

\begin{tabular}{lr}
\hline & $\begin{array}{c}\text { Unstandardized } \\
\text { Residual }\end{array}$ \\
\hline Test Value $^{\mathrm{a}}$ & -0.06716 \\
\hline Cases < Test Value & 44 \\
\hline Cases >= Test Value & 45 \\
\hline Total Cases & 89 \\
\hline Number of Runs & 54 \\
\hline Z & 1.814 \\
\hline Asymp. Sig. (2-tailed) & 0.070 \\
\hline
\end{tabular}

Sumber: Data SPSS yang diolah, 2021 
Berdasarkan tabel di atas diketahui bahwa Asymp. Sig. (2-tailed) berada diatas 0.05. Nilai diatas 0.05 mengindikasiikan bahwa tidak terdapat masalah autokorelasi.

\section{Uji Heteroskedastisitas}

Uji heteroskedastisitas dilakukan untuk mendeteksi apakah model regresi dalam analisis path antar nilai residual memiliki hubungan yang signifikan dengan variabel bebas. Model regresi yang terbaik adalah apabila antara residual dengan variabel bebas model tidak saling berhubungan. Pendeteksian atas asumsi non autokorelasi dilakukan dengan metode Glejser dengan hasil sebagai berikut:

Tabel 6. Hasil Uji Heteroskedastisitas

\begin{tabular}{|c|c|c|c|c|c|c|}
\hline \multirow{2}{*}{\multicolumn{2}{|c|}{ Model }} & \multicolumn{2}{|c|}{$\begin{array}{c}\text { Unstandardized } \\
\text { Coefficients }\end{array}$} & \multirow{2}{*}{$\begin{array}{c}\text { Standardized } \\
\text { Coefficients } \\
\text { Beta }\end{array}$} & \multirow[t]{2}{*}{$\mathrm{t}$} & \multirow[t]{2}{*}{ Sig. } \\
\hline & & $B$ & $\begin{array}{c}\text { Std. } \\
\text { Error }\end{array}$ & & & \\
\hline \multirow[t]{3}{*}{1} & (Constant) & 0.311 & 0.025 & & 12.300 & 0.000 \\
\hline & Kualitas Laba & -0.124 & 0.064 & -0.204 & -1.947 & 0.055 \\
\hline & $\begin{array}{l}\text { Manipulasi } \\
\text { LK }\end{array}$ & 0.001 & 0.001 & 0.129 & 1.235 & 0.220 \\
\hline
\end{tabular}

Sumber: Data SPSS yang diolah, 2021

Berdasarkan tabel di atas terlihat bahwa nilai signifikansi berada diatas 0.05 sehingga disimpulkan tidak ada masalah heteroskedastisitas dalam model.

\section{Analisis Regresi}

Setelah pengujian terhadap normalitas dan asumsi klasik terpenuhi, selanjutnya akan dilakukan uji regresi. Berikut hasil pengujian terhadap model regresi dengan bantuan SPSS:

Tabel 7. Hasil Analisis Regresi

\begin{tabular}{lccc}
\hline \multicolumn{1}{c}{ Pengaruh } & t Value & Signifikansi & Keterangan \\
\hline $\begin{array}{l}\text { Kualitas Laba } \rightarrow \text { Nilai } \\
\text { Perusahaan }\end{array}$ & -4.026 & 0 & Signifikan \\
\hline $\begin{array}{l}\text { Manipulasi LK } \rightarrow \text { Nilai } \\
\text { Perusahaan }\end{array}$ & -0.556 & 0.58 & Tidak Signifikan \\
\hline $\begin{array}{l}\text { Sumber: Data SPSS yang diolah, 2021 } \\
\text { Sumban }\end{array}$ & & &
\end{tabular}

Nilai-nilai koefisien regresi di atas dapat dituliskan menjadi persamaan sebagai berikut: Nilai perusahaan $=-4.026$ KualitasLaba -0.556 ManipulasiLK

Nilai koefisien variabel kualitas laba terhadap nilai perusahaan adalah -4.026. Artinya, jika kualitas laba suatu perusahaan meningkat satu kali standar deviasi, maka nilai perusahaan perusahaan tersebut akan berkurang sebesar 4.026 kali standar deviasi. Nilai koefisien variabel manipulasi LK terhadap nilai perusahaan adalah -0.556. Artinya, jika manipulasi laporan keuangan suatu perusahaan meningkat satu kali standar deviasi, maka nilai perusahaan perusahaan tersebut akan berkurang sebesar 0.556 kali standar deviasi.

\section{Pengujian Hipotesis}

Pengujian hipotesis dilakukan dengan melihat nilai signifikansi hubungan antar variabel. Tingkat toleransi yang digunakan adalah 5\%. Jika nilai koefisien antar variabel signifikan, 
berarti hipotesis tidak diterima. Akan tetapi jika nilai koefisien antar variabel tidak signifikan, berarti hipotesis diterima. Berikut adalah hasil pengujian hipotesis:

Tabel 8. Hasil Pengujian Hipotesis

\begin{tabular}{lccc}
\hline \multicolumn{1}{c}{ Pengaruh } & Signifikansi & Keterangan & Keputusan \\
\hline $\begin{array}{l}\text { Kualitas Laba } \rightarrow \text { Nilai } \\
\text { Perusahaan }\end{array}$ & 0.00 & Signifikan & Diterima \\
\hline $\begin{array}{l}\text { Manipulasi LK } \rightarrow \text { Nilai } \\
\text { Perusahaan }\end{array}$ & 0.58 & Tidak & Signifikan \\
\hline
\end{tabular}

Sumber: Data SPSS yang diolah, 2021

Pengaruh kualitas laba yang diukur dengan discretionary acrual terhadap nilai perusahaan adalah negatif signifikan. Dengan demikian kualitas laba berpengaruh terhadap nilai perusahaan yang diukur dengan kinerja pasar tobins'q diterima kebenarannya.

Pengaruh manipulasi laporan keuangan yang diukur dengan M Score model terhadap nilai perusahaan negatif tidak signifikan. Dengan demikian manipulasi laporan keuangan tidak berpengaruh terhadap nilai perusahaan yang diukur dengan kinerja pasar tobins'q tidak diterima kebenarannya.

\section{Pembahasan}

Perhitungan statistik menemukan bahwa kualitas laba berpengaruh negatif signifikan terhadap kinerja pasar perusahaan. Hasil ini mengindikasikan bahwa semakin tinggi kualitas laba perusahaan, maka nilai perusahaan akan semakin rendah. Temuan ini bertentangan dengan teori dan beberapa peneliti sebelumnya seperti penelitian Lestari et al. (2014), Hamdiah (2015), Subagya (2017) dan Utomo dan Dianawati (2017). Penyebab perbedaan temuan ini dengan penelitian lainnya adalah penurunan harga saham perusahaan-perusahaan pertambangan khususnya batubara di akhir tahun 2018 dimana perusahaan batubara merupakan penggerak sektor petambangan di Indonesia (Kurniawan, 2018). Penurunan harga komoditas merupakan bad news bagi pemegang saham perusahaan pertambangan karena akan menurunkan harga saham di pasar modal secara cepat. Sempat terjadi sedikit kenaikan di sektor pertambangan di kuartal 1 tahun 2019, tetapi menurun lagi di kuartal 2 dan 3 tahun 2019 (Lawi, 2019).

Sektor pertambangan merupakan sektor yang penuh resiko dan return yang besar. Fluktuasi harga saham di sektor ini cenderung volatile dan susah diprediksi meskipun menggunakan analisis teknikal dan fundamental. Jadi, meskipun kinerja perusahaan baik di tahun t, belum tentu harga saham akan mengikuti nya di tahun t. Selain itu, penggunaan tobins'q dengan dasar harga penutupan saham tahunan perusahaan sebagai proksi dari penilaian kinerja pasar perusahaan akan membuat nilai koefisiennya semakin rendah.

Untuk tingkat manipulasi laporan keuangan diketahui bahwa tidak terdapat pengaruh yang signifikan terhadap kinerja pasar perusahaan. Hasil ini mengindikasikan bahwa para pelaku pasar sektor pertambangan di periode pengamatan 2017 sampai 2019 tidak menggunakan informasi ini dalam menentukan keputusan pembelian saham, padahal di beberapa penelitian terdahulu sebagian besar menyimpulkan bahwa M Score model sebagai proksi dari tingkat manipulasi laporan keuangan mampu mendeteksi kecurangan dalam laporan keuangan perusahaanperusahaan (Tarjo dan Herawati, 2015; Repousis, 2016; Talab et al, 2017; Iswanaji, 2018; dan Hugo, 2019). Para pelaku pasar sektor pertambangan menggunakan indikator lain dalam menilai kinerja pasar perusahaan seperti ROA, PBV, PER atau bahkan menggunakan analisis teknikal dalam penilaiannya.

Hasil temuan ini juga membantah pendapat Novriansa (2019) yang mengatakan bahwa sektor pertambangan merupakan sektor yang rawan kecurangan. Variabel tingkat manipulasi laporan keuangan yang dihitung dengan $\mathrm{M}$ score model menunjukkan rata-rata -6.608 dimana 
angka ini mengindikasikan bahwa kecil kemungkinan terjadinya kecurangan dalam perusahaan dengan acuan threshold -1.78 (Robinson et al., 2015). Berikut tampilan M score model untuk tahun 2017, 2018, dan 2019:

Tabel 9. Tabel Hasil M Score Model Tiap Sampel

\begin{tabular}{|c|c|c|c|c|c|}
\hline \multirow[t]{2}{*}{ No } & \multirow[t]{2}{*}{ Kode } & \multirow[t]{2}{*}{ Nama Emiten } & \multicolumn{3}{|c|}{ M Score } \\
\hline & & & 2017 & 2018 & 2019 \\
\hline 1 & ADRO & Adaro Energy Tbk & -2.92 & -3.43 & -3.21 \\
\hline 2 & ARII & Atlas Resources Tbk & -1.76 & -3.53 & -2.71 \\
\hline 3 & BUMI & Bumi Resources Tbk & -2.63 & 54.46 & -2.80 \\
\hline 4 & BYAN & Bayan Resources Tbk & -2.57 & -3.03 & -0.25 \\
\hline 5 & DOID & Delta Dunia Makmur Tbk & -3.64 & -3.74 & -3.39 \\
\hline 6 & DSSA & Dian Swastatika Sentosa Tbk & 0.18 & -3.38 & -3.08 \\
\hline 7 & FIRE & Alfa Energi Investama Tbk & -1.62 & -363.66 & -2.71 \\
\hline 8 & GEMS & Golden Energi Mines Tbk & -3.02 & -2.33 & -2.97 \\
\hline 9 & HRUM & Harum Energy Tbk & -2.74 & -3.18 & -2.64 \\
\hline 10 & INDY & Indika Energy Tbk & -1.89 & -1.63 & -6.17 \\
\hline 11 & KKGI & Resource Alam Indonesia Tbk & -3.35 & -2.34 & -2.32 \\
\hline 12 & MBAP & Mitrabara Adiperdana Tbk & -3.28 & -3.69 & -3.84 \\
\hline 13 & $\mathrm{MYOH}$ & Samindo Resource Tbk & -4.02 & -3.90 & -3.00 \\
\hline 14 & PKPK & Perdana Karya Perkasa Tbk & -27.79 & -3.63 & -6.38 \\
\hline 15 & PTBA & Bukit Asam Tbk & -2.24 & -3.57 & -2.92 \\
\hline 16 & PTRO & Petrosea Tbk & -3.59 & 4.66 & -2.05 \\
\hline 17 & SMMT & Golden Eagle Energy Tbk & -2.67 & -8.90 & -2.80 \\
\hline 18 & ELSA & Elnusa Tbk & -3.27 & -3.22 & -3.37 \\
\hline 19 & ESSA & Surya Eka Perkasa Tbk & -2.76 & -1.00 & -2.95 \\
\hline 20 & MEDC & Medco Energi Internasional Tbk & -1.19 & -1.98 & -3.13 \\
\hline 21 & MITI & Mitra Investindo Tbk & -3.11 & -2.53 & -11.19 \\
\hline 22 & RUIS & Radiant Utama Interinsco Tbk & -3.48 & -3.15 & -3.29 \\
\hline 23 & ANTM & Aneka Tambang Tbk & -2.77 & 3.66 & -2.99 \\
\hline 24 & CITA & Cita Mineral Investindo Tbk & -2.67 & -1.29 & -2.15 \\
\hline 25 & DKFT & Central Omega Resources Tbk & -4.87 & -3.70 & -3.09 \\
\hline 26 & INCO & Vale Indonesia Tbk & -3.67 & -3.29 & -3.47 \\
\hline 27 & MDKA & Merdeka Copper Gold Tbk & -5.45 & -2.23 & -3.25 \\
\hline 28 & SMRU & SMR Utama Tbk & -2.99 & -3.92 & -4.15 \\
\hline 29 & TINS & Timah Tbk & -2.93 & -2.81 & -2.58 \\
\hline 30 & ZINC & Kapuas Prima Coal Tbk & -0.97 & -2.66 & -3.34 \\
\hline & & ta-rata tiap Tahun & -3.66 & -12.76 & -3.41 \\
\hline
\end{tabular}

Sumber: Hasil Perhitungan Laporan Keuangan, 2017-2019

Jika melihat pada rata-rata M Score model tiap tahunnya dan menggunakan acuan thres hold -1.78 (Robinson et al., 2015), maka secara keseluruhan tidak ditemukan adanya indikasi manipulasi atas laporan keuangan perusahaan pertambangan meskipun tidak $100 \%$ perusahaan pertambangan bebas dari manipulasi. 


\section{SIMPULAN}

Penelitian ini bertujuan untuk melihat apakah kualitas laba dan tingkat manipulasi laporan keuangan berpengaruh terhadap nilai pasar perusahaan sehingga pada nantinya akan digunakan oleh pelaku pasar sebagai informasi tambahan dalam melakukan kegiatan investasinya. Berdasarkan hasil penelitian ditemukan bahwa kualitas laba berpengaruh negative terhadap nilai pasar perusahaan sedangkan tingkat manipulasi laporan keuangan tidak berpengaruh terhadap nilai pasar perusahaan. Keterbatasan dalam penelitian ini adalah penggunaan sampel yang hanya 3 tahun dan pada akhir 2018 sektor pertambangan dalam kondisi mengalamai penurunan harga komoditas terutama sector batubara. Kondisi ini kemungkinan menyebabkan hasil penelitian berbeda dengan penelitian lainnya dan juga teori. Untuk penelitian selanjutnya, bisa menggunakan 5 tahun pengamatan diluar tahun 2018 dan 2019.

\section{DAFTAR PUSTAKA}

Hamdiah, C. (2015). Pengaruh Kepemilikan Institusional Dan Kualitas Laba Terhadap Nilai Perusahaan Pada Perusahaan Transportasi Yang Terdaftar Di Bursa Efek Indonesia. Jurnal Ekonomi Manajemen Dan Akuntansi, 1(1), 1-9.

Hugo, J. (2019). Efektivitas Model Beneish M-score dan Model F-score dalam Mendeteksi Kecurangan Laporan Keuangan. Jurnal Muara Ilmu Ekonomi Dan Bisnis, 3(1), 165. https://doi.org/10.24912/jmieb.v3i1.2296

Islam, M. A., Ali, R., \& Ahmad, Z. (2011). Is Modified Jones Model Effective in Detecting Earnings Management? Evidence from A Developing Economy. International Journal of Economics and Finance, 3(2), 116-125. https://doi.org/10.5539/ijef.v3n2p116

Iswanaji, C. (2018). Mendeteksi Kecurangan Laporan Keuangan Menggunakan Beneish Ratio Index Pada Pabrik Cambric Yogyakarta. Jurnal Reviu Akuntansi Dan Keuangan, 8(1), 2534. https://doi.org/10.22219/jrak.v8i1.24

Kurniawan, R. (2018). Harga Batubara Terendah dalam 6 Bulan Terakhir, Bagaimana Prospek Emiten Pertambangan Batu bara? https://rivankurniawan.com/2018/12/11/penurunanharga-batubara/

Lawi, G. F. K. (2019). Ekonomi Kuartal II/2019, Sektor Pertambangan dan Penggalian Turun 0,71 Persen.

Lestari, N. B., Khafid, M., \& Anisykurlillah, I. (2014). Pengaruh Good Corporate Governance terhadap Nilai Perusahaan dengan Kualitas Laba Sebagai Variabel Intervening. Accounting Analysis Journal, 3(1), 34-43.

Novriansa, A. (2019). Sektor Pertambangan Rawan Manipulasi Transfer Pricing? DDTC News. https://news.ddtc.co.id/sektor-pertambangan-rawan-manipulasi-transfer-pricing17422?page_y $=0$

Repousis, S. (2016). Using Beneish model to detect corporate financial statement fraud in Greece. Journal of Financial Crime, 23(4), 1063-1073. https://doi.org/10.1108/JFC-112014-0055

Robinson, T. R., Henry, E., Pirie, W. L., \& Broihahn, M. A. (2015). International Financial Statement Analysis (CFA Institute Investment Series) (3rd Edition). In BMC Public Health (3rd ed., Vol. 5, Issue 1). Wiley.

Subagya, Y. H. (2017). Keterkaitan Kepemilikan Manajerial, Institusional, dan Komite Audit pada Nilai Perusahaan di Mediasi Oleh Kualitas Laba. Jurnal Perilaku Dan Strategi Bisnis, 5(2), 117-132. https://doi.org/10.26486/jpsb.v5i2.353

Talab, H. R., Hammood, H., \& Ali, S. I. (2017). Role of Beneish M-score model in Detecting of Earnings Management Practices: Empirical Study in listed banks of Iraqi Stock Exchange. International Journal of Applied Business and Economic Research, 15(23). 
Tarjo, \& Herawati, N. (2015). Application of Beneish M-score Models and Data Mining to Detect Financial Fraud. 2nd Global Conference on Business and Social Science-2015, 211(September), 924-930. https://doi.org/10.1016/j.sbspro.2015.11.122

Utomo, F. M., \& Dianawati, W. (2017). Corporate Governance dan Leverage terhadap Nilai Perusahaan Dengan Kualitas Laba Sebagai Variabel Mediasi. Jurnal Investasi Islam, 2(2), 21-44.

Watts, R. L., \& Zimmerman, J. L. (1990). Positive Accounting Theory: A Ten Year Perspective. The Accounting Review, 65(1), 131-156.

Yoon, S. S., Miller, G., \& Jiraporn, P. (2006). Earnings management vehicles for Korean firms. Journal of International Financial Management and Accounting, 17(2), 85-109. https://doi.org/10.1111/j.1467-646X.2006.00122.x

Zarviana, R., Nur, E., \& Indrawati, N. (2017). Pengaruh IFR dan Mekanisme CG terhadap Nilai Perusahaan dengan Kualitas Laba sebagai Variabel Intervening. Jurnal Sorot, 12(1), 25-39. https://doi.org/10.31258/sorot.12.1.4079 